\title{
EFFECT OF COPPER SUPPLEMENTATION ON OVARIAN FUNCTION AND BLOOD PROFILES OF NATIVE GOATS IN GRAZING COPPER-DEFICIENT ALFALFA DESERT OASIS
}

\author{
SENOSY W. ${ }^{1}$; KASSAB A.Y. ${ }^{2}$; EZZAT A. AHMED ${ }^{3}$ and MOHAMMED A.A ${ }^{4}$ \\ ${ }^{1}$ Department of Theriogenology, Faculty of Veterinary Medicine, New Valley University, \\ AL Kharga City, New Valley, 51714, Egypt \\ ${ }^{2}$ Department of Animal Production, Faculty of Agriculture, New Valley University, AL Kharga City, \\ New Valley, 51714, Egypt \\ ${ }^{3}$ Biology Department, Faculty of Science, King Khalid University, 61413 Abha, Saudi Arabia. Department of \\ Theriogenology, Faculty of Veterinary Medicine, South Valley University, Qena, 83523, Egypt \\ ${ }^{4}$ Department of Animal Production, Faculty of Agriculture, Assiut University, Egypt, 71526
}

Received: 25 December 2018; Accepted: 31 January 2019

\begin{abstract}
The effects of copper supplementation were studied in twenty female native goats grazing irrigated alfalfa and supplemented with corn, $250 \mathrm{~g} / \mathrm{day}$ in a copper-deficient oasis in the Egyptian desert in an experiment for 5 weaks. The alfalfa was low in copper $(3.8 \mathrm{ppm})$ and high in iron $(482 \mathrm{ppm})$. The animals were divided into two groups of 10 animals each. The first group was orally supplemented with $15 \mathrm{ml}$ copper sulfate solution daily and the second group was kept as control. Number and sizes of ovarian follicles were recorded three times per week during week 4 and 5 from the onset of treatment. Plasma metabolites, hormones and copper concentrations were determined. Numbers and sizes of follicles were significantly $(\mathrm{P}<0.05)$ increased by copper treatment. Pregnancy rate was high $(\mathrm{P}<0.05)$ in copper group $(100 \%)$ if compared to control $(67 \%)$. Plasma concentrations of total protein, albumin, creatinine, glucose (during week 5 of treatment), triiodothyronine (T3) and thyroxin (T4; during weeks 3,4 and 5 of treatment) were higher $(\mathrm{P}<0.05)$ in copper group. Plasma concentrations of total cholesterol and blood urea nitrogen decreased $(\mathrm{P}<0.05)$ whereas concentration of progesterone during luteal phase was higher in copper group than that of control $(3.42 \pm 0.29 \mathrm{ng} / \mathrm{ml} v s .2 .65 \pm 0.44 \mathrm{ng} / \mathrm{ml} ; \mathrm{P}<0.05)$. In conclusions, blood metabolites, ovarian activity and reproductive performance could be improved as results of copper sulfate administration to native goats in subtropics $\mathrm{Cu}$-deficient oasis.
\end{abstract}

Key words: Copper, Follicles, Ovaries, Blood Metabolites, Goat, Progesterone.

\section{INTRODUCTION}

Copper is a vital dietary nutrient needed in small quantities and necessary for maintaining reproduction and blood hemoglobin levels (Araya et al., 2006). Copper absorption is low $(<1.0-10.0 \%)$ in ruminants relative to values indicated in nonruminant animals (Underwood and Suttle 1999). Imbalances of trace metals as zinc, molybdenum, sulfur and iron decreased bio-availability of copper (Radostits et al., 2007). Deficiency of copper in grazing ruminants is a worldwide problem (Underwood and Suttle 1999). In western Egyptian desert, copper deficiency was reported in soil, pasture, and grazing sheep (Yousef 2006). Moreover, soil, water and forages in some areas of El-Kharga

Corresponding author: Waleeed Senosy E-mail address: senosy_76@yahoo.com

Present address: Department of Theriogenology, Faculty of Veterinary Medicine, New Valley University, AL Kharga City, New Valley, 51714, Egypt oasis are deficient in copper and zinc whereas iron and manganese are presented in high concentrations (Sanosi et al., 2015).

The disturbances of trace minerals may directly affect the performances of animals. Copper deficiency has adverse effects on the immune system, iron deficient anemia, growth and fertility (Galbat et al., 2015; Sakhaee et al., 2011). Earlier reports stated that copper administration can induce ovulation in ewes through stimulating the release of both gonadotrophin releasing hormone (GnRH) (Murawski et al., 2006) through the effective combination of copper with gonadotropin-releasing hormone $(\mathrm{GnRH})$ to $\mathrm{LH}$ release (Michaluk and Kochman (2007).

Our hypothesis stated that copper supplementation to animals in deficient area could improve metabolic and reproductive status. In subtropical conditions of New Valley governorate, this study was carried out for five weeks to determine the effects of copper sulphate supplementation on reproductive activities as 
ovarian follicles numbers and sizes, corpora lutea sizes, hematological profiles, metabolites and hormonal profile in native goats.

\section{MATERIALS AND METHODS}

The experiment was carried out following the procedures approved by the Ethics Committee on Animal Experimentation of Assiut University, Faculty of Veterinary Medicine.

\section{The area of study}

The area of study is a part of New Valley governorate, an area well known as mineral-deficient (Saleh et al. 2008), which is an oasis located in the Western Tropical Egyptian Desert. El-Kharga oasis is a depression of Western Egyptian Desert extends between longitude $28^{\circ} 30^{\prime}$ and $30^{\circ} 47^{\prime} \mathrm{E}$ and latitude $25^{\circ} 15^{\prime}$ and $27^{\circ} 00^{\prime} \mathrm{N}$. Rainfall is negligible and consequently no rivers or surface water is presented.

\section{Experimental design}

Twenty female native goats (13-15 months and $29.2 \pm 0.30 \mathrm{~kg}$ body weight), were divided into control (10 females) and copper treated group (10 females). Clinically, animals were apparently healthy (normal body temperature, pulse and respiration), anemia and discolored coat was the only prominent clinical sign of the Cu-deficient goats in addition to lower pregnancy rate of the whole herd annually (55.0\%). Goats were fed mainly on grazing Alfalfa (Medicago sativa) pastures grown around ground-water wells in addition to $250 \mathrm{~g}$ corn /head/ day with free access to water.

\section{Food and blood sampling and analysis}

Representative samples (5 samples, $50 \mathrm{~g}$ each) of grazing Alfalfa (Medicago sativa) were collected from pastures around groundwater wells the $\mathrm{Cu}$ deficient areas. Samples of each area were pooled into one sample, dried, ground and stored in air-tight containers for subsequent analysis.

Animals had a plasma $\mathrm{Cu}$ concentration of $5.84 \pm$ $0.43 \mu \mathrm{mol} / 1$ (ranged between 4.59 and $6.67 \mu \mathrm{mol} / 1$ ) and were considered marginally $\mathrm{Cu}$ deficient (Saleh, et al., 2008). Each Doe of treated copper group was orally supplemented with $15 \mathrm{ml}$ copper sulfate solution (15 mg inorganic copper; $1 \mathrm{~g}$ copper sulfate) daily for five weeks whereas control group received $15 \mathrm{ml}$ physiological saline.

\section{Ultrasonographic examination of ovarian activity}

Does were trans-rectally investigated by ultrasonography device (Pie medical, 100 LC, Holland) at the start of the experiment. They were all suffered from ovarian sub-function and the ovaries containing small $(<3 \mathrm{~mm})$ and medium sized $(3-4.9$ $\mathrm{mm}$ ) follicles except 2 animals (are cyclic and possess functioning corpus luteum). Routine ultrasonographic examination was carried out also during the $4^{\text {th }}$ and $5^{\text {th }}$ week of the experiment every other day. Ovarian follicles and corpora lutea development and diameter were estimated using the internal caliper of the sonographic apparatus. Oestrus of native goats was detected by checking goats' behavior (refusal or standing heat) after introducing a buck once daily. The numbers of ovarian follicles $\geq 2$ $\mathrm{mm}$ in diameters were measured and their relative positions were recorded on the ovarian maps to follow their sequential development. During the estrous cycle, the mean number of small (diameter 2$2.9 \mathrm{~mm}$ ), medium (diameter $3-5 \mathrm{~mm}$ ), large follicles (diameter $>5 \mathrm{~mm}$ ) and the mean day of emergence of ovulatory follicles (>2 $\mathrm{mm}$ ) were recorded.

\section{Blood metabolites and hormones analyses}

Blood samples $(10 \mathrm{ml})$ were collected through jugular vein puncture from each animal on biweekly basis during week 3, 4 and 5 of copper treatment period in tubes containing $0.14 \%$ anticoagulant (EDTA K3, Pty Ltd., Adelaide, SA, Australia). Blood plasma samples were obtained by centrifugation of blood samples for $10 \mathrm{~min}$ at $2000 \mathrm{xg}$ at room temperature $\left(25^{\circ} \mathrm{C}\right)$ and stored at $\left(-20{ }^{\circ} \mathrm{C}\right)$ till assay for further analysis of plasma metabolites (total protein, albumin, creatinine, glucose, total cholesterol and blood urea nitrogen (BUN) concentrations), enzymes (alanine transaminase (ALT), aspartate transaminase (AST), alkaline phosphatase, creatine kinase), hormones (Triiodothyronine; T3, Thyroxine; T4, estradiol and progesterone) and copper. Estradiol was measured once during detected estrus in copper and control groups to confirm estrus in Does. Progesterone was assessed during diestrus period. Plasma concentrations of metabolites, enzymes and minerals were determined by spectrophotometer (Unico, USA) using commercial test kits (Spectrum Company, Egypt); glucose by the enzymatic colorimetric method (Weissmann and Klein, 1958), total protein by Biuret reagent (Gornall et al., 1949), globulin and albumin by bromocresol green reaction (Doumas et al., 1971), total cholesterol (Ellefson and Caraway 1979), urea (Tietz 1990). Concentrations of blood plasma estradiol and progesterone hormones were determined using direct ELISA Kits provided by Diagnostic System Laboratory Co. (DSL, Catalogue No. 3900, USA). The intra-and interassay coefficient of variations were 4.8 and $9.2 \%$, for estradiol and 3.6 and $12.43 \%$ for progesterone, respectively. The sensitivity of the assay was $2 \mathrm{pg} / \mathrm{ml}$ for E2 and 0.12 $\mathrm{ng} / \mathrm{ml}$ for P4. Plasma concentration of T3 and T4 was estimated by using direct ELISA kits (CALBIOTECH, Catalogue No. T3225T, USA). The intra-and interassay coefficient of variations of $\mathrm{T}_{3}$ were 7.2 and $9.1 \%$, respectively. They were 6.6 and $6.2 \%$ of $\mathrm{T}_{4}$. The sensitivity of the assay was 0.16 $\mathrm{ng} / \mathrm{ml}$ for $\mathrm{T}_{3}$ and $2 \mathrm{ng} / \mathrm{ml}$ for $\mathrm{T}_{4}$.

\section{Hematological investigations}

Blood samples were collected at biweekly intervals during weeks 3,4 and 5 of copper treatment period (6 
samples collectively for each animal). Values of red blood cells (RBC) was determined using a hemocytometer, whereas packed cell volume (PCV) and hemoglobin concentration $(\mathrm{Hb})$ were determined by microhematocrit and cyanomethemoglobin methods, respectively (Jain 1986).

\section{Copper determination}

Copper concentration in fresh alfalfa and corn were determined by atomic absorption spectrophotometer (GBC 932 AA; GBC Scientific Equipment, Australia) after wet ashing in perchloric, nitric and sulfuric acids. Plasma copper concentrations were determined colorimery using commercial kits (Sigma, Egypt) and spectrophotometer (GBC 932 AA; GBC Scientific Equipment, Australia).

\section{Statistical analysis}

The results were subjected to statistical analysis with a repeated measures model (SPSS for Windows Version 16; SPSS GmbH, Munich, Germany).

Duncan's multiple range test was used to detect differences among means for plasma metabolites (total protein, albumin, globulin, urea, creatinine, glucose, total cholesterol), enzymes (AST, ALT, alkaline phosphatase, CrK, Alkaline phosphatase) and hormones (T3, T4, estradiol and progesterone), minerals (copper) and hematological data. Differences between treatment means regarding duration of estrus, mean number of different types of follicles and maximum size of the largest follicles were determined by independent t-test. Comparisons between proportions of animals resuming ovarian activity (detected estrus) and pregnancy rate was performed by a Chi square test using pairwise comparisons of the proportions. Data are presented as mean \pm SEM. Values of probability were considered significant of less than 0.05 .

\section{RESULTS}

\section{Estrus detection and ovarian follicular development}

Results in Table (1) indicated that copper treatment improved oestrus display, plasma progesterone and oestradiol concentrations.

Table 1: Reproductive parameters $($ Mean \pm SEM) in copper $(n=10)$ and control native goats $(n=10)$ during weeks 4 and 5 from the onset of the treatment

\begin{tabular}{ccc}
\hline Reproductive parameters & Copper group & Control group \\
\hline Does showing estrus & 7 & 3 \\
\hline Days to first estrus & $18.9 \pm 0.19$ & $22.7 \pm 0.52$ \\
\hline Estrus duration (hrs) & $34.8 \pm 0.43$ & $35.6 \pm 0.72$ \\
\hline Mean diameter of CL $(\mathrm{mm})$ & $8.7 \pm 0.34$ & $8.1 \pm 0.25$ \\
\hline Mean progesterone level during luteal phase $(\mathrm{ng} / \mathrm{ml})$ & $3.42 \pm 0.29^{\mathrm{a}}$ & $2.65 \pm 0.44^{\mathrm{b}}$ \\
\hline Mean estradiol level at detected estrus $(\mathrm{pg} / \mathrm{ml})$ & $18.6 \pm 0.79^{\mathrm{a}}$ & $16.04 \pm 0.52^{\mathrm{b}}$ \\
\hline Pregnancy rate $(\%)$ & $7 / 7^{\mathrm{a}}$ & $2 / 3^{\mathrm{b}}$
\end{tabular}

Values with different superscripts within the same raw between groups was significant $(\mathrm{a}, \mathrm{b} \mathrm{P}<0.05)$

Data in Table (2) indicated that number of follicles of all sizes was more in treated than untreated goats. Large follicles increased in size with advancement of treatment in copper supplemented goats when compared to the control.

Table 2: Ovarian structures (Mean follicle number and diameter; Mean \pm SEM) in copper ( $\mathrm{n}=10)$ and control $(\mathrm{n}=10)$ native goats during week 4 and 5 from the onset of treatment.

\begin{tabular}{ccccccccc}
\hline & \multicolumn{3}{c}{ Copper group $(\mathrm{n}=10)$} & \multicolumn{3}{c}{ Control group $(\mathrm{n}=10)$} \\
\cline { 2 - 8 } Examination & No SF & No MF & No LF & $\begin{array}{c}\text { Size of LF } \\
(\mathrm{mm})\end{array}$ & No SF & No MF & $\begin{array}{c}\text { No LF } \\
\text { nyyyyyyyyyy}\end{array}$ & $\begin{array}{c}\text { Size of LF } \\
(\mathrm{mm})\end{array}$ \\
\hline Week 4 (1) & $4.9 \pm 0.5^{\mathrm{a} 1}$ & $2.3 \pm 0.2^{\mathrm{a} 1}$ & $1.3 \pm 0.2^{\mathrm{a} 1}$ & $5.0 \pm 0.2^{\mathrm{a} 1}$ & $3.5 \pm 0.5^{\mathrm{b} 1}$ & $1.8 \pm 0.4^{\mathrm{b} 1}$ & $1.3 \pm 0.4^{\mathrm{a} 1}$ & $4.6 \pm 0.2^{\mathrm{b} 1}$ \\
Week 4 (2) & $4.8 \pm 0.5^{\mathrm{a} 1}$ & $2.3 \pm 0.2^{\mathrm{a} 1}$ & $1.3 \pm 0.2^{\mathrm{a} 1}$ & $5.0 \pm 0.2^{\mathrm{a} 1}$ & $3.8 \pm 0.5^{\mathrm{b} 2}$ & $1.9 \pm 0.4^{\mathrm{b} 1}$ & $1.2 \pm 0.4^{\mathrm{a} 1}$ & $4.4 \pm 0.2^{\mathrm{b} 2}$ \\
Week 4 (3) & $4.9 \pm 0.5^{\mathrm{a} 1}$ & $2.3 \pm 0.2^{\mathrm{a} 1}$ & $1.3 \pm 0.3^{\mathrm{a} 1}$ & $5.0 \pm 0.3^{\mathrm{a} 1}$ & $4.1 \pm 0.5^{\mathrm{b} 3}$ & $1.9 \pm 0.3^{\mathrm{b} 1}$ & $1.0 \pm 0.4^{\mathrm{b} 2}$ & $4.4 \pm 0.2^{\mathrm{b} 2}$ \\
Week 5 (1) & $4.8 \pm 0.4^{\mathrm{a} 1}$ & $2.5 \pm 0.3^{\mathrm{a} 2}$ & $1.9 \pm 0.3^{\mathrm{a} 2}$ & $5.2 \pm 0.3^{\mathrm{a} 2}$ & $4.1 \pm 0.5^{\mathrm{b} 3}$ & $1.9 \pm 0.3^{\mathrm{b} 1}$ & $1.1 \pm 0.4^{\mathrm{b} 1}$ & $4.6 \pm 0.2^{\mathrm{b} 1}$ \\
Week 5 (2) & $5.3 \pm 0.5^{\mathrm{a} 2}$ & $2.5 \pm 0.3^{\mathrm{a} 2}$ & $1.9 \pm 0.2^{\mathrm{a} 2}$ & $5.2 \pm 0.3^{\mathrm{a} 2}$ & $4.1 \pm 0.4^{\mathrm{b} 3}$ & $1.9 \pm 0.3^{\mathrm{b} 1}$ & $1.1 \pm 0.4^{\mathrm{b} 2}$ & $4.8 \pm 0.2^{\mathrm{b} 1}$ \\
Week 5 (3) & $5.0 \pm 0.5^{\mathrm{a} 3}$ & $2.5 \pm 0.2^{\mathrm{a} 2}$ & $1.9 \pm 0.2^{\mathrm{a} 2}$ & $5.2 \pm 0.3^{\mathrm{a} 2}$ & $4.1 \pm 0.5^{\mathrm{b} 3}$ & $1.9 \pm 0.3^{\mathrm{b} 1}$ & $1.2 \pm 0.4^{\mathrm{b} 2}$ & $4.7 \pm 0.2^{\mathrm{b} 1}$ \\
\hline
\end{tabular}

Values with different superscripts $(a, b)$ within the same raw of the same category in both groups was significant $(\mathrm{p}<0.05)$

Values with different numeric $(1,2)$ within the same column was significant $(\mathrm{P}<0.05)$

SF: small follicles < 3mm; MF: medium sized follicles $(3-5 \mathrm{~mm})$; LF: large sized follicles $>5 \mathrm{~mm}$.

Week 4 and 5 from the onset of copper treatment 


\section{Mineral concentrations in food and experimental goats}

$\mathrm{Cu}$-deficient forage was lower in $\mathrm{Cu}$ than the requirement of goat $(12.2 \mathrm{ppm})$, whereas concentrations of other minerals ( $\mathrm{Zn}$, Mo and $\mathrm{S}$ ) were normal in the two pastures but Fe was high in pasture $(\mathrm{P}<0.05$; Table 3).

Table 3: Mineral concentrations in pasture grazed by goats where studied animals were obtained.

\begin{tabular}{ccc}
\hline Item & Normal pasture & Deficient pasture \\
\hline $\mathrm{Cu}(\mathrm{ppm})$ & 12.2 & 3.8 \\
$\mathrm{Mo}(\mathrm{PPM})$ & 0.40 & 0.52 \\
$\mathrm{~S}(\%)$ & 0.21 & 0.22 \\
$\mathrm{Fe}(\mathrm{ppm})$ & 408 & 482 \\
$\mathrm{Zn}(\mathrm{ppm})$ & 33.4 & 33.2 \\
\hline
\end{tabular}

The present results in Table (4) indicated that plasma copper concentrations $(\mu \mathrm{mol} / \mathrm{l})$ were always significantly $(\mathrm{P}<0.01)$ higher in copper group than control one.

Table 4: Blood concentrations of copper and thyroid hormones (Mean \pm SEM) of copper $(n=10)$ and control native goats during week 3,4 and 5 from the onset of treatment.

\begin{tabular}{|c|c|c|c|c|c|c|c|}
\hline \multirow{2}{*}{ Items } & \multirow{2}{*}{ Group } & \multicolumn{6}{|c|}{ Week of examination } \\
\hline & & Week 3 (1) & Week 3 (2) & Week 4 (1) & Week 4 (2) & Week $5(1)$ & Week $5(2)$ \\
\hline \multirow{2}{*}{$\begin{array}{l}\text { Copper } \\
\mu \mathrm{mol} / \mathrm{l}\end{array}$} & Copper & $11.8 \pm 1.1^{\mathrm{c} 1}$ & $12.5 \pm 0.3^{\mathrm{c} 1}$ & $11.5 \pm 1.1^{\mathrm{c} 1}$ & $12.4 \pm 0.9^{c 1}$ & $12.2 \pm 0.7^{\mathrm{c} 1}$ & $12.1 \pm 1.1^{\mathrm{c} 1}$ \\
\hline & Control & $5.8 \pm 0.7^{\mathrm{d} 1}$ & $5.4 \pm 0.3^{\mathrm{d} 1}$ & $5.5 \pm 0.1^{\mathrm{d} 1}$ & $6.2 \pm 0.1^{\mathrm{d} 1}$ & $6.3 \pm 0.9^{\mathrm{d} 1}$ & $6.8 \pm 1.1^{\mathrm{d} 1}$ \\
\hline \multirow{2}{*}{$\begin{array}{c}\mathrm{T} 3 \\
\mathrm{ng} / \mathrm{ml}\end{array}$} & Copper & $1.5 \pm 0.1^{1}$ & $1.7 \pm 0.1^{\mathrm{a} 2}$ & $1.7 \pm 0.1^{\mathrm{a} 2}$ & $1.7 \pm 0.1^{\mathrm{a} 2}$ & $1.8 \pm 0.1^{\mathrm{a} 2}$ & $1.8 \pm 0.1^{\mathrm{a} 2}$ \\
\hline & Control & $1.5 \pm 0.1^{1}$ & $1.3 \pm 0.2^{\mathrm{b} 2}$ & $1.3 \pm 0.2^{\mathrm{b} 2}$ & $1.4 \pm 0.2^{\mathrm{b} 2}$ & $1.1 \pm 0.1^{\mathrm{b} 3}$ & $1.1 \pm 0.1^{\mathrm{b} 3}$ \\
\hline \multirow[b]{2}{*}{$\begin{array}{c}\mathrm{T} 4 \\
\mathrm{ng} / \mathrm{ml}\end{array}$} & Copper & $5.7 \pm 0.4^{1}$ & $7.0 \pm 0.5^{\mathrm{a} 2}$ & $7.1 \pm 0.5^{\mathrm{a} 2}$ & $8.9 \pm 0.4^{\mathrm{a} 3}$ & $6.9 \pm 0.3^{\mathrm{a} 2}$ & $5.7 \pm 0.5^{\mathrm{a} 1}$ \\
\hline & Control & $4.4 \pm 0.3^{1}$ & $4.9 \pm 0.6^{\mathrm{b} 1}$ & $5.0 \pm 0.6^{\mathrm{b} 1}$ & $5.3 \pm 0.5^{\mathrm{b} 1}$ & $4.1 \pm 0.3^{\mathrm{b} 1}$ & $4.2 \pm 0.3^{\mathrm{b} 1}$ \\
\hline
\end{tabular}

Values with different superscripts in the same column between groups differ significantly (a,b: $\mathrm{P}<0.05 ; \mathrm{c}, \mathrm{d} \mathrm{P}<0.01$ )

Values with different numeric $(1,2,3)$ within the same row was significant $(\mathrm{P}<0.05)$

\section{Hematological parameters}

Blood profiles including red blood cells $\left(\mathrm{RBC}, \mathrm{x} 10^{6}\right)$, packed cell volume (PCV, \%) hemoglobin $(\mathrm{Hb}, \mathrm{mg} / \mathrm{dl}) \mathrm{in}$ copper group were always significantly $(\mathrm{P}<0.05)$ higher than that of control group (fig. 1$)$. 

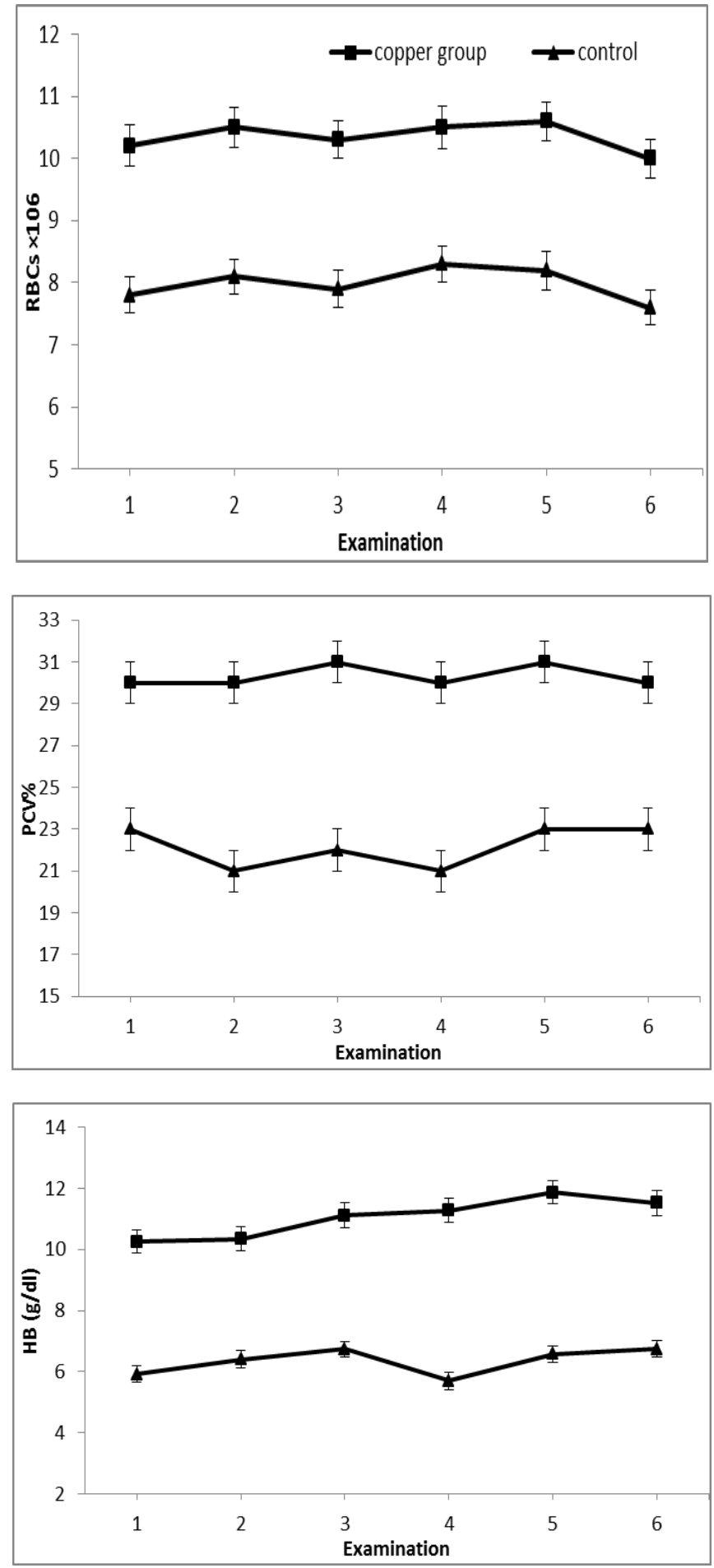

Fig. 1: Changes of red blood cells $\left(\mathrm{RBC}, \mathrm{X} 10^{6}\right)$, packed cell volume $(\mathrm{PCV}, \%)$ and hemoglobin $(\mathrm{Hb}, \mathrm{g} / \mathrm{dl})$ in copper treated and control group

\section{Blood metabolites and hormones concentrations} Triiodothryroxine (T3) hormone (ng/ml) concentrations in copper group was higher $(\mathrm{P}<0.05)$ when compared to the control group at fourth examination time (table 4). Thyroxin (T4) hormone $(\mathrm{ng} / \mathrm{ml})$ concentrations of copper group were significantly $(\mathrm{P}<0.05)$ higher than that of control group at second examination time.
In table 5, levels of total proteins $(\mathrm{g} / \mathrm{dl})$ of copper group were significantly $(\mathrm{P}<0.05)$ higher than control group at the sixth examination time. Concentration of blood urea nitrogen $(\mathrm{mg} / \mathrm{dl})$ during sixth examination time was lower $((\mathrm{P}<0.05)$ in copper group $(17.15 \pm$ $0.58)$ than that of control $(19.61 \pm 0.78)$. Furthermore, creatinine concentration $(\mathrm{mg} / \mathrm{dl})$ was significantly $\mathrm{P}<0.05)$ higher in copper group than that of control during sixth examination time. 
Table 5: Blood metabolites concentrations (Mean \pm SEM) in copper $(n=10)$ and control $(n=10)$ native goats during week 3, 4 and 5 from the onset of treatment.

\begin{tabular}{|c|c|c|c|c|c|c|c|}
\hline \multirow[t]{2}{*}{ Item } & \multirow[t]{2}{*}{ Group } & \multicolumn{6}{|c|}{ Week of examination } \\
\hline & & Week $3(1)$ & Week 3 (2) & Week 4 (1) & Week 4 (2) & Week $5(1)$ & Week 5 (2) \\
\hline \multirow{2}{*}{$\begin{array}{l}\text { Total protein } \\
\mathrm{g} / \mathrm{dl}\end{array}$} & Copper & $5.9 \pm 0.2^{1}$ & $6.1 \pm 0.2^{1}$ & $6.4 \pm 0.2^{2}$ & $6.7 \pm 0.2^{3}$ & $6.9 \pm 0.2^{3}$ & $7.6 \pm 0.2^{\mathrm{a} 3}$ \\
\hline & Control & $6.0 \pm 0.2^{1}$ & $6.1 \pm 0.2^{1}$ & $6.3 \pm 0.2^{1}$ & $6.4 \pm 0.21^{1}$ & $6.5 \pm 0.2^{1}$ & $6.8 \pm 0.2^{\mathrm{b} 2}$ \\
\hline \multirow{2}{*}{$\begin{array}{l}\text { Albumin } \\
\mathrm{g} / \mathrm{dl}\end{array}$} & Copper & $3.0 \pm 0.0^{1}$ & $3.2 \pm 0.1^{2}$ & $3.3 \pm 0.0^{2}$ & $3.3 \pm 0.1^{2}$ & $3.4 \pm 0.0^{\mathrm{a} 3}$ & $3.5 \pm 0.1^{\mathrm{a} 3}$ \\
\hline & Control & $3.1 \pm 0.1^{1}$ & $3.1 \pm 0.1^{1}$ & $3.2 \pm 0.1^{1}$ & $3.2 \pm 0.1^{1}$ & $3.3 \pm 0.1^{\mathrm{b} 2}$ & $3.3 \pm 0.1^{\mathrm{b} 2}$ \\
\hline \multirow{2}{*}{$\begin{array}{l}\text { Globulin } \\
\text { g/dl }\end{array}$} & Copper & $2.9 \pm 0.2^{1}$ & $3.0 \pm 0.2^{1}$ & $3.1 \pm 0.1^{1}$ & $3.3 \pm 0.2^{2}$ & $3.5 \pm 0.1^{2}$ & $4.1 \pm 0.2^{\mathrm{a} 3}$ \\
\hline & Control & $2.9 \pm 0.2$ & $3.0 \pm 0.2$ & $3.1 \pm 0.2$ & $3.2 \pm 0.2$ & $3.3 \pm 0.2$ & $3.5 \pm 0.3^{b}$ \\
\hline \multirow{3}{*}{$\begin{array}{c}\text { A/G ratio } \\
\% \\
\text { Urea } \\
\mathrm{mg} / \mathrm{dl}\end{array}$} & Copper & $1.0 \pm 0.1^{1}$ & $1.1 \pm 0.1^{2}$ & $1.1 \pm 0.1^{2}$ & $1.0 \pm 0.1^{1}$ & $1.0 \pm 0.1^{1}$ & $0.8 \pm 0.1^{3}$ \\
\hline & Control & $1.1 \pm 0.1^{1}$ & $1.0 \pm 0.1^{2}$ & $1.0 \pm 0.1^{2}$ & $1.0 \pm 0.1^{2}$ & $1.0 \pm 0.0^{2}$ & $1.0 \pm 0.0^{2}$ \\
\hline & Copper & $19.2 \pm 0.6^{1}$ & $18.2 \pm 1.0^{1}$ & $17.8 \pm 0.6^{2}$ & $17.7 \pm 0.7^{2}$ & $17.1 \pm 0.5^{2}$ & $17.2 \pm 0.6^{\mathrm{a} 2}$ \\
\hline \multirow{2}{*}{$\begin{array}{l}\text { Creatinine } \\
\mathrm{mg} / \mathrm{dl}\end{array}$} & Control & $18.3 \pm 0.7^{1}$ & $18.6 \pm 0.6^{1}$ & $18.8 \pm 0.9^{1}$ & $18.7 \pm 0.8^{1}$ & $18.8 \pm 1.1^{1}$ & $19.6 \pm 0.8^{\mathrm{bl}}$ \\
\hline & Copper & $1.3 \pm 0.1^{1}$ & $1.3 \pm 0.0^{1}$ & $1.4 \pm 0.1^{2}$ & $1.4 \pm 0.1^{2}$ & $1.5 \pm 0.1^{3}$ & $1.5 \pm 0.1^{\mathrm{a} 3}$ \\
\hline \multirow{3}{*}{$\begin{array}{l}\text { Glucose } \\
\text { mg/dl }\end{array}$} & Control & $1.3 \pm 0.1^{1}$ & $1.3 \pm 0.1^{1}$ & $1.3 \pm 0.1^{1}$ & $1.2 \pm 0.1^{2}$ & $1.2 \pm 0.1^{2}$ & $1.2 \pm 0.1^{\mathrm{b} 2}$ \\
\hline & Copper & $65.5 \pm 1.2^{1}$ & $69.1 \pm 1.3^{2}$ & $\begin{array}{c}67.4 \pm \\
1.3^{1,2} \\
\end{array}$ & $70.0 \pm 1.6^{2}$ & $72.4 \pm 1.7^{2}$ & $73.1 \pm 1.7^{\mathrm{a} 2}$ \\
\hline & Control & $63.7 \pm 1.6^{1}$ & $68.0 \pm 1.9^{2}$ & $67.3 \pm 1.6^{2}$ & $69.8 \pm 1.2^{2}$ & $68.3 \pm 1.8^{2}$ & $69.8 \pm 1.7^{\mathrm{b} 2}$ \\
\hline \multirow[t]{2}{*}{$\begin{array}{c}\text { Cholesterol } \\
\mathrm{mg} / \mathrm{dl}\end{array}$} & Copper & $77.4 \pm 3.0^{1}$ & $83.3 \pm 4.6^{2}$ & $81.1 \pm 4.7^{2}$ & $81.1 \pm 4.7^{2}$ & $81.5 \pm 5.1^{2}$ & $85.6 \pm 5.0^{\mathrm{a} 2}$ \\
\hline & Control & $77.0 \pm 3.9^{1}$ & $83.3 \pm 4.8^{2}$ & $84.7 \pm 3.8^{2}$ & $87.3 \pm 4.6^{2}$ & $86.6 \pm 3.2^{2}$ & $93.0 \pm 1.7^{\mathrm{b} 3}$ \\
\hline
\end{tabular}

Values with different superscripts $(\mathrm{a}, \mathrm{b})$ in the same column between groups differ significantly $(\mathrm{P}<0.05)$

Values with different numeric $(1,2,3)$ within the same row was significant $(\mathrm{P}<0.05)$

In table 6 , creatine kinase concentration $(\mathrm{U} / \mathrm{L})$ was significantly $(\mathrm{P}<0.05)$ higher in control group when compared to copper group during forth examination time.

Table 6: Concentrations of enzymes and minerals (Mean \pm SEM) in copper $(n=10)$ and control $(n=10)$ native goats during week 3,4 and 5 from the onset of treatment.

\begin{tabular}{|c|c|c|c|c|c|c|c|}
\hline \multirow{2}{*}{ Item } & \multirow{2}{*}{ Group } & \multicolumn{6}{|c|}{ Week of examination } \\
\hline & & Week 3 (1) & Week 3 (2) & Week $4(1)$ & Week 4 (2) & Week $5(1)$ & Week 5 (2) \\
\hline \multirow{2}{*}{$\begin{array}{c}\text { AST } \\
\text { U/1 }\end{array}$} & Copper & $97.5 \pm 5.8$ & $102.0 \pm 3.1$ & $100.3 \pm 5.4$ & $102.2 \pm 5.2$ & $101.0 \pm 4.1$ & $103.3 \pm 2.3$ \\
\hline & Control & $99.6 \pm 4.5^{1}$ & $100.7 \pm 4.4^{1}$ & $104.5 \pm 3.5^{1}$ & $104.2 \pm 3.8^{1}$ & $108.0 \pm 1.8^{2}$ & $107.8 \pm 2.7^{2}$ \\
\hline \multirow{2}{*}{$\begin{array}{c}\text { ALT } \\
\mathrm{U} / \mathrm{l}\end{array}$} & Copper & $30.0 \pm 2.3$ & $31.3 \pm 2.9$ & $32.2 \pm 2.7$ & $33.4 \pm 2.2$ & $35.3 \pm 1.3$ & $33.0 \pm 2.6$ \\
\hline & Control & $31.6 \pm 2.6^{1}$ & $33.2 \pm 2.7^{1}$ & $34.4 \pm 2.7^{1,2}$ & $34.5 \pm 2.1^{1,2}$ & $36.6 \pm 2.5^{2}$ & $36.8 \pm 2.3^{2}$ \\
\hline \multirow{5}{*}{$\begin{array}{c}\text { Alkaline } \\
\text { phosphatase } \\
\text { IU/l } \\
\text { Creatine } \\
\text { kinase U/l }\end{array}$} & Copper & $109.9 \pm 0.9$ & $109.7 \pm 1.4$ & $111.8 \pm 1.4$ & $112.0 \pm 1.3$ & $112.5 \pm 1.5$ & $113.3 \pm 1.1$ \\
\hline & Control & $111.0 \pm 1.3$ & $111.9 \pm 1.4$ & $112.9 \pm 1.3$ & $113.3 \pm 1.4$ & $114.0 \pm 1.4$ & $115.3 \pm 1.2$ \\
\hline & & & & & & & \\
\hline & Copper & $87.1 \pm 1.7$ & $87.1 \pm 1.2$ & $86.9 \pm 1.0$ & $87.4 \pm 0.9$ & $88.1 \pm 1.4$ & $89.3 \pm 1.9$ \\
\hline & Control & $87.8 \pm 1.4^{1}$ & $89.4 \pm 1.1^{1}$ & $90.4 \pm 1.6^{1,2}$ & $91.1 \pm 1.3^{1,2}$ & $92.5 \pm 1.3^{2}$ & $92.5 \pm 2.0^{2}$ \\
\hline
\end{tabular}

$\mathrm{AST}=$ Aspartate aminotransferase; ALT=Alanine aminotransferase

Values with different numeric $(1,2)$ within the same row was significant $(\mathrm{P}<0.05)$ 


\section{DISCUSSIONS}

The current work accepted our hypothesis which showed that $\mathrm{Cu}$ supplementation, has a significant effect on ovarian structures development, blood metabolites and endocrine profiles of blood in native goats in subtropics $\mathrm{Cu}$-deficient area.

The present results indicated that the concentrations of copper in fresh alfalafa (Medicago sativa) were low in $\mathrm{Cu}$, which accompanied with high $\mathrm{Fe}$ concentrations, explains the development of clinical $\mathrm{Cu}$ deficiency leading to copper deficiency in native goat. The most likely cause of copper deficiency in a diet may be due to $\mathrm{Cu}$ :Fe antagonism (Suttle, 2010). Iron was higher in soil with subsequent higher dietary Fe overload that decrease copper activity (Cockell et al., 2005). Earlier reports stated that grazing sheep in Egyptian oases suffered from $\mathrm{Cu}$ deficiency (Saleh et al., 2008).

Goats at the beginning of the study showed low hemoglobin values $(5.92 \mathrm{mg} / \mathrm{dl})$ and low pregnancy rates annually $(55.0 \%)$. Copper concentration increased as a result of $\mathrm{Cu}$ supplementation during our study compared with control group is consistent with the results obtained by Zhang et al. (2008) in Cashmere goats and Engle and Spears (2000) in steers. Our results opposed that obtained by Eckert et al. (1999) who found no changes of plasma $\mathrm{Cu}$ in ewes receiving different levels of copper.

The present results of reproductive performance indicated that the numbers and sizes of ovarian follicles increased in copper group if compared to the control one. Copper could result in disruption of endocrine secretions and interfere with key enzymes expression involved in steroidogenesis (Sanderson 2006), which can change hormones concentrations (Gracia et al., 2006; Zhang et al., 2005) and reproductive functions (Reeder et al., 2005). Oetradiol and progesterone hormones are steroids synthesized from cholesterol through a series of reactions (Ačimovič and Rozman 2013). It has been indicated that copper deficiency resulted in abnormalities in glucose and cholesterol metabolism (Roughead and Lukaski 2003). Copper administration can induce ovulation in ewes (Murawski et al., 2006) through stimulating the release of both gonadotrophin releasing hormone (GnRH) and LH (Hazum 1983). Michaluk and Kochman (2007) have indicated that combination of copper with gonadotropin-releasing hormone $(\mathrm{GnRH})$ is exceedingly effective in the release of LH hormone.

Concerning the effect of $\mathrm{Cu}$ on blood profiles, the control $\mathrm{Cu}$-deficient group had a low red blood cells count in addition to variations in RBCs shape and size. Normal accepted values for hemoglobin are considered 8-12 g/dl. Galbat et al. (2015) found low hemoglobin values in $\mathrm{Cu}$-deficient kids was $7.25 \pm$
$0.15 \mathrm{~g} / \mathrm{dl}$ and high neutrophiles and monocytes counts. The $\mathrm{Cu}$-deficient animals showed paleness and weakness in their mucous membranes. The anemia observed of the $\mathrm{Cu}$ deficient group is macrocytic and hypochromic anemia (MCHC; < 30 $\mathrm{g} / \mathrm{dl}$ in control group $v s$. $>38 \mathrm{~g} / \mathrm{dl}$ in treated group), which is concomitant with those earlier studies reported by Church and Pond 1998.

Supplementation of copper sulfate solution within copper group improved total protein, albumin, globulin, creatinine and glucose. These positive effects may be due to increasing the concentration of thyroid hormone, which had positive effect on metabolism. Generally, concentrations of different plasma metabolites were high due to $\mathrm{Cu}$ supplementation especially during fifth examination.

\section{CONCLUSIONS}

Supplementation of copper to native goats in copper deficient oasis area is necessary and leads to positive effects on reproductive performances and health.

\section{ACKNOWLEDGMENTS}

The authors thank staff member of native Goat farm in $\mathrm{Al}$ Kharga Oasis, New Valley governorate

\section{CONFLICT OF INTEREST}

The authors declare no conflicts of interest.

\section{REFERENCES}

Ačimovič, J. and Rozman, D. (2013): Steroidal Triterpenes of Cholesterol Synthesis. Molecules, 18, 4002-4017.

Araya, M.; Pizarro, F.; Olivares, M.; Arredondo, M.; Gonzalez, M. and Méndez, M. (2006): Understanding copper homeostasis in humans and copper effects on health. Biol. Res. 39, 183-187.

Church, CD. and Pond, WG. (1998): Fundamentos de nutrición y alimentación de animales, Editorial Limusa S.A. de C.V. Grupo Noriega Editores, México D.F., pp, 189-192.

Cockell, KA.; Wotherspoon, AT.; Belonje, B.; Fritz, ME.; Madère, R.; Hidiroglou, N.; Plouffe, LJ.; Ratnayake, WM. and Kubow, S. (2005): Limited effects of combined dietary copper deficiency/iron overload on oxidative stress parameters in rat liver and plasma. J. Nut. Biochem 16(12), 750-6.

Correa, LB.; Zanetti, MA.; Del Claro, GR.; De Melo MP.; Rosa, AF. and Netto, AS. (2012): Effect of supplementation of two sources and two levels of copper on lipid metabolism in Nellore beef cattle. Meat Sci. 91, 466-471. 
Doumas, BT.; Watson, WA. and Biggs, HG. (1971): Albumin standards and the measurement of serum albumin with bromcresol green. Clin Chim Acta. 31(1): 87-96.

Eckert, GE.; Greene, LW.; Carstens, GE. and Ramsey, WS. (1999): Copper status of ewes fed increasing amounts of copper from copper sulfate or copper proteinate. J. Anim. Sci. 77, 244-249.

EfrénRamírez Bribiesca, J.; Casas, RL.; Monterrosa, RG. and Pérez, AR. (2017): Supplementing selenium and zinc nanoparticles in ruminants for improving their bioavailability meat. Nutrition Delivery, Pp. 713-747.

Ellefson, R.D. and Caraway, W.T. (1979): Lipids and lipoproteins. In: N.W. Tietz (Ed.), Fundamentals of linical chemistry (p. 506). Philadelphia, PA: W.B. Saunders.

Engle, TE. and Spears, JW. (2000): Dietary copper effects on lipid metabolism, performance, and ruminal fermentation in finishing steers. J. Anim. Sci. 78, 2452-2458.

Galbat, SA.; Abdel-Fattah, SM. and Yehia, HA. (2015): Some Clinicopathological and haematological Studies on Copper deficiency in sheep in South Sinai region of Egypt. Int. J. Adv. Res., 3(11), 650 - 656.

Gracia, T.; Hilscherova, K.; Jones, PD.; Newsted, JL.; Zhang, X.; Hecker, M.; Higley, EB.; Sanderson, JT.; Yu RMK.; Wu, RSS. and Giesy, JP. (2006): The H295R system for evaluation of endocrine-disrupting effects. Ecotoxicol. Environ. Saf. 65, 293-305. DOI: 10.1016/j.ecoenv.2006.06.012

Gornall, AG.; Bardawill, CJ. and David, MM. (1949): Determination of serum proteins by means of the biuret reaction. J Biol Chem, 177(2): 751-66.

Hazum, E. (1983): Copper and thiol regulation of gonadotropin releasing hormone binding and luteinizing hormone release. Biochem Biophys Res Commun. 15;112(1): 306-12.

Jain, NC. (1986): Hematologic techniques. In: Jain, N.C. (Ed.), Schalm's Veterinary Hematology, 4th ed. Lea and Febiger, Philadelphia, pp. 20-86.

Michaluk, A. and Kochman, K. (2007): Involvement of copper in female reproduction. Reprod. Biol. 7(3), 193-205.

Murawski, M.; Bydłoń, G.; Sawicka-Kapusta, K.; Wierzchoś, E.; Zakrzewska, M. and Wtodarczyk, S. (2006): The effect of long term exposure to copper on physiological condition and reproduction of sheep. Reprod. Biol. 6 (suppl 1), 201-216.

NRC (2007): Nutrient requirements of small ruminants, sheep, goats, carvivdsis and new worled camelids the National Academies Press, Washington, D. C.
Radostits, OM.; Gay, CC.; Hinchcliff, $K W$. and Constable, PD. (2007): Veterinary medicine. Saunders Elsevier, Philadelphia, 1707-1732

Reeder, AL.; Ruiz MO.; Pessier, A.; Brown, LE.; Levengood, JM.; Phillips, CA.; Wheeler, MB.; Warner, RE. and Beasley, VR. (2005): Intersexuality and the cricket frog decline: historic and geographic trends. Environ. Health Perspect., 113, 261-265.

Roughead, ZK. and Lukaski, HC. (2003): Inadequate copper intake reduces serum insulin-like growth factor-I and bone strength in growing rats fed graded amounts of copper and zinc. $\mathbf{J}$. Nut., 33, 442-448.

Sakhaee, E.; Emadi, L.; Kheirandish, R.; Azari, O.; Abshenas, J. and Amiri, E. (2011): Evaluation of epididymal sperm quality, and histopathological assessment of male reproductive organ, following experimentally induced copper poisoning in rat. Androl., 144, 110-116.

Saleh, MA.; Al-Salahy, MB. and Sanousi, SA. (2008): Corpuscular oxidative stress in desert sheep naturally deficient in copper. Small Rum. Res., $80,33-38$

Sanderson, JT. (2006): The steroid hormone biosynthesis pathway as a target for endocrinedisrupting chemicals. Rev. Toxicol. Sci., 94, 3-21. DOI:10.1093/toxsci/kfl051

Sanosi, SA.; Abou El-Wafa, SA.; Rateb, MH. and Saleh, MA. (2015): Trace element concentrations in ill-thrift calves in relation to the ecology of El-Kharga oasis, the new-valley province, Egypt. Assiut Vet. Med. J., 61(144), 145-150.

Saxena, KK. and Ranjhan, SK. (1978): Effect of cobalt and copper supplementation, separately and in combination, on the digestibility of organic nutrients and mineral balances in Hariana calves. Ind. J. Anim. Sci., 48, 566-571.

Suttle, NF. (2010): Mineral nutrition of livestock. $4^{\text {th }}$ edition, CABI, Cambridge.

Tietz, N.W. (Ed.) (1990): Clinical guide to laboratory tests, 2nd ed. (p. 566). Philadelphia: W.B. Saunders.

Underwood, EJ. and Suttle, NF. (1999): The Mineral Nutrition of Livestock, $3^{\text {rd }}$ ed 1999, CABI Publishing Co., New York.

Yousef, EM. (2006): Some minerals profile in sheep serum in New-Valley governorate. MVSc Thesis, Faculty of Veterinary Medicine, Assiut University, Assiut, Egypt.

Weissmann, M. and Klein, B. (1958): Evaluation of glucose determination in untreated serum samples. Clinical Chemistry, 4, 420-422.

Zhang, W.; Wang, R.; Kleemann, DO.; Lu, D.; Zhu, X.; Zhang, C. and Jia, Z. (2008): Effects of dietary copper on nutrient digestibility, growth performance and plasma copper status in 
cashmere goats. Small Rum. Res., 74, 188-193.

Zhang, X.; Yu, RM.; Jones, PD.; Lam, GK.; Newsted, JL.; Gracia, T.; Hecker, M.; Hilscherova, K.; Sanderson, T.; Wu, RS. and Giesy, JP. (2005):
Quantitative RT-PCR methods for evaluating toxicant-induced effects on steroidogenesis using the H295R cell line. Environ. Sci. Tech., 39(8), 2777-2785.

\section{اثر إضافة النحاس على وظيفة المبيض ودلاثل الدم فى الماعز المحلى في مراعى البرسيم الواحاتى التى تعانى من نقص التص ولبي سنوسسى ، أبين بيوسف كساب ، أحمد عزت أحمد ، عبل الناصر محمد}

Email: senosy_76@yahoo.com Assiut University web-site: www.aun.edu.eg

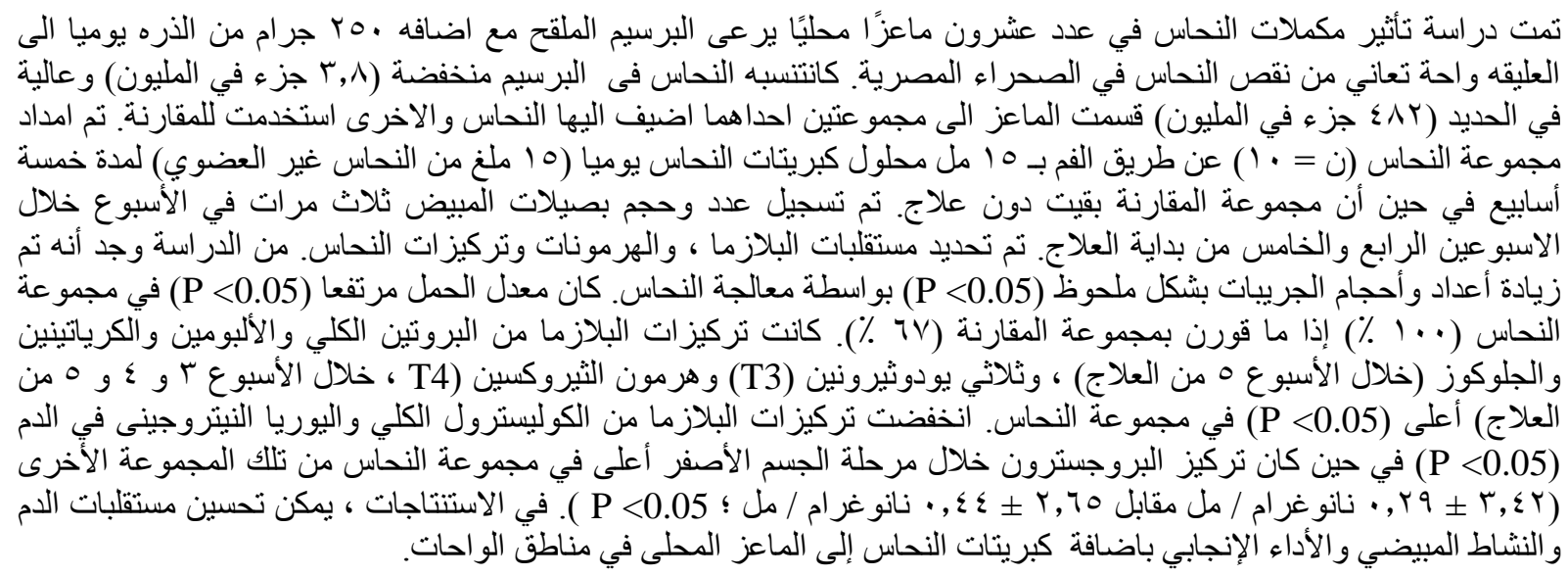

